\title{
Dynamic Behavior of Segmented- in-Series Tubular Solid Oxide Fuel Cell upon Discharge
}

\section{AUTHOR(S):}

Liu, Bin; Muroyama, Hiroki; Matsui, Toshiaki;

Tomida, Kazuo; Kabata, Tatsuo; Eguchi, Koichi

\section{CITATION:}

Liu, Bin ... [et al]. Dynamic Behavior of Segmented-in-Series Tubular Solid Oxide Fuel Cell upon Discharge. Journal of The Electrochemical Society 2012, 159(3): B324-B330

\section{ISSUE DATE:}

2012-01-13

URL:

http://hdl.handle.net/2433/193704

\section{RIGHT:}

(C) The Electrochemical Society, Inc. 2012. All rights reserved. Except as provided under U.S. copyright law, this work may not be reproduced, resold, distributed, or modified without the express permission of The Electrochemical Society (ECS). 


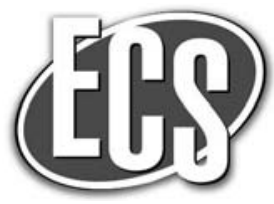

\title{
Dynamic Behavior of Segmented-in-Series Tubular Solid Oxide Fuel Cell upon Discharge
}

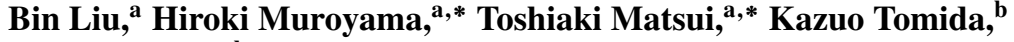 \\ Tatsuo Kabata, ${ }^{\mathrm{b}}$ and Koichi Eguchi ${ }^{\mathrm{a}, *, \mathrm{z}}$
}

\author{
${ }^{a}$ Department of Energy and Hydrocarbon Chemistry, Graduate School of Engineering, Kyoto University, \\ Nishikyo-ku, Kyoto 615-8510, Japan \\ ${ }^{b}$ New Energy Systems Department, Mitsubishi Heavy Industries, Ltd., Nagasaki 850-8610, Japan
}

\begin{abstract}
Dynamic behavior of the segmented-in-series tubular solid oxide fuel cell upon discharge was investigated. The cell performance decreased initially at $900^{\circ} \mathrm{C}$, accompanied by the increase of ohmic resistance. Lower partial pressure of oxygen in the cathode resulted in a more severe decrease, whereas the gas displacement in the anode compartment did not induce such behavior. As the current was cut off, the ohmic resistance rapidly recovered toward the starting value before current load. The possible origin for this increase-recovery behavior of the ohmic resistance has been discussed based on the evaluation of oxygen partial pressure at the cathode/electrolyte interface and element interdiffusion between cathode and electrolyte.

(c) 2012 The Electrochemical Society. [DOI: 10.1149/2.099203jes] All rights reserved.
\end{abstract}

Manuscript submitted October 5, 2011; revised manuscript received December 19, 2011. Published January 13, 2012.

Solid oxide fuel cell (SOFC) is an efficient power generation system that directly converts the chemical energy stored in the fuel and oxidant to the electrical energy. Although there are no concentration gradients of gases in both electrodes at open circuit voltage (OCV), the partial pressures of fuel and oxidant reduce along the gas flow channel under current loading conditions. The electrochemical reaction proceeds at the triple phase boundary (TPB) near the electrode/electrolyte interface. Thus, more severe fuel or oxidant concentration gradients build up locally near the electrode/electrolyte interface. The significantly lower fuel and oxidant concentrations in the vicinity of TPB can induce the changes in local electrode surface chemistry and interfacial microstructure, both of which decide the cell dynamic behavior. Two possible electrode dynamic behaviors are expected upon discharge, i.e., electrode activation and electrode degradation.

During the initial period of current load, the electrochemical performance of SOFC is improved significantly, depending on the cell components. This behavior is well known as the electrode activation. In contrast to the weak activation of $\mathrm{Ni} / \mathrm{Y}_{2} \mathrm{O}_{3}$-stabilized $\mathrm{ZrO}_{2}$ (YSZ) anode, the activation of $(\mathrm{La}, \mathrm{Sr}) \mathrm{MnO}_{3}(\mathrm{LSM})$ cathode is dominant in the overall cell activation. ${ }^{1-3}$ The LSM activation essentially corresponds to the enhancement of activity for oxygen reduction reaction upon discharge. The oxygen reduction reaction comprises a series of elementary steps, i.e., the oxygen gas adsorption and dissociation on the electrode surface, the surface diffusion of the adsorbed oxygen species toward TPB, the ionization of the adsorbed oxygen species and incorporation of the ionized oxygen species into the LSM vacancies. The activation of LSM results from the changes in chemical composition and microstructure at the cathode/electrolyte interface; (1) the partial reduction of manganese species $\left(\mathrm{Mn}^{4+}\right.$ to $\mathrm{Mn}^{3+}$, $\mathrm{Mn}^{3+}$ to $\mathrm{Mn}^{2+}$ ) with concomitant generation of additional oxygen vacancies; ${ }^{4-6}(2)$ the disappearance of the insulative phases such as $\mathrm{La}_{2} \mathrm{Zr}_{2} \mathrm{O}_{7}$, formed at the LSM/YSZ interface during the fabrication process ${ }^{7,8}$ (3) the change of LSM surface composition such as the removal of the passive species, $\mathrm{SrO} ;{ }^{9}, 10$ and (4) the microstructural change at the cathode/electrolyte interface. ${ }^{1-13}$ Once the current is cut off, the cell terminal voltage returns to OCV almost instantaneously. However, the recovery of the impedance spectrum measured at OCV requires a much longer time. This process is termed as the electrode relaxation. Jiang et al. observed the cathode polarization resistance recovered close to the starting value after holding at OCV for $67 \mathrm{~h} .{ }^{14}$ Koch et al. found the cell resistance increased significantly over the next 4 days at open circuit conditions. ${ }^{2}$ The relaxation of LSM is related to the disappearance of oxygen vacancies and the reconstruction

\footnotetext{
* Electrochemical Society Active Member.

${ }^{\mathrm{z}}$ E-mail: eguchi@scl.kyoto-u.ac.jp
}

of cation vacancies. The former is a rapid process, whereas the latter is much slower since the cation diffusion coefficient is about three to four orders of magnitude lower than that of oxygen at the same temperature and oxygen partial pressure. ${ }^{14}$ On the impedance spectra, the activation of LSM is identified as a significant decrease of a specified impedance arc, which is greatly affected by the magnitude of current load. The relaxation process is indicated by its recovery with the prolonged time.

In our previous studies, ${ }^{15,16}$ the individual electrode processes of the anode and cathode have been separated from impedance spectra consisting of several overlapped components after exclusion of highfrequency inductive component for the segmented-in-series tubular SOFC. The gas transport impedance has been intensively discussed. In this work, our objective is to investigate the dynamic behavior of the cell upon discharge. To clearly observe the change in the cell performance during the initial stage of current load, the current load cycling tests were conducted. Electrochemical impedance spectroscopy was used to monitor the variation of the electrode kinetics induced by the current load.

\section{Experimental}

Cell geometry.- The segmented-in-series SOFC short stack was fabricated by Mitsubishi Heavy Industries, Ltd. The cell fabrication procedures have been reported elsewhere. ${ }^{17,18}$ Figure 1 shows the schematic diagram of the two-cell short stack employed in this study. Two serially-connected single cells with identical size and fabrication processes were numbered as cell 1 and cell 2. Each single cell consists of seven components; $(\mathrm{La}, \mathrm{Sr})(\mathrm{Ca}, \mathrm{Mn}) \mathrm{O}_{3}$ (LSCM) cathode current collecting layer, LSM/YSZ cathode active layer, YSZ electrolyte, $\mathrm{Ni} / \mathrm{YSZ}$ anode active layer, Ni/YSZ anode current collecting layer, $\mathrm{CaO}$-stabilized $\mathrm{ZrO}_{2}$ substrate and $(\mathrm{La}, \mathrm{Sr}) \mathrm{TiO}_{3}$ interconnector. The slurries of the anodes, the anode interlayers, the electrolytes, and the interconnectors were serially screen-printed on the substrate tubes and co-sintered in air at $1400 \sim 1460^{\circ} \mathrm{C}$ for $4 \mathrm{~h}$. Afterward, the slurries of the cathode active layers and cathode current collecting layers were serially screen-printed on the aforementioned cosintering assemble and subsequently baked in air at $1300 \sim 1365^{\circ} \mathrm{C}$ for $2 \mathrm{~h}$. Details of the textual parameters of a single cell are described in Ref. 16. The dimensions of the cell components have been designed so as to be suitable for the basic electrochemical evaluation. The distance between the neighboring cathodes is $8 \mathrm{~mm}$. The internal diameter of the porous substrate is $16.5 \mathrm{~mm}$. The internal and external diameters of the cathode chamber are 25.5 and $42 \mathrm{~mm}$, respectively. The effective area of power generation for one single cell is $6.91 \mathrm{~cm}^{2}$. 

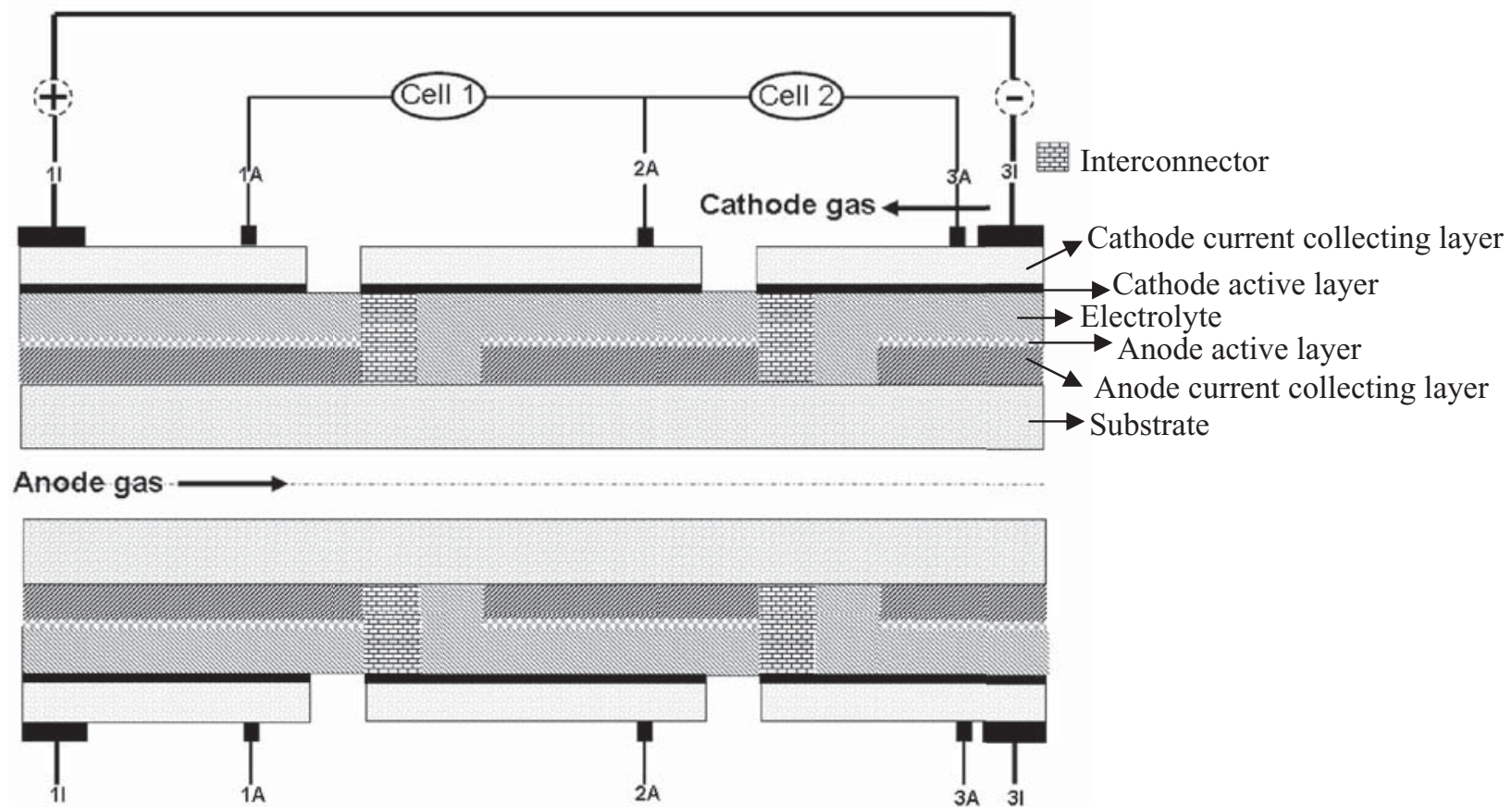

Figure 1. The schematic diagram of the two-single-cell stack.

Cell test. - The fuel and oxidant were supplied in the counter-flow direction, and the operating temperature was fixed at $900^{\circ} \mathrm{C}$. Pt wires of $1 \mathrm{I}$ and $3 \mathrm{I}$ work as the current lead wires. The wires of $1 \mathrm{~A}$ and $2 \mathrm{~A}$ work as the voltage lead wires for cell 1 , and $2 \mathrm{~A}$ and $3 \mathrm{~A}$ serve as the voltage lead wires for cell 2 . The test apparatus can be seen in Ref. 16. All the electrochemical tests were carried out on cell 1 . The test conditions were denoted in each figure. The impedance spectra were performed by Solartron 1260 combined with Solartron 1287, and recorded with the ac-amplitude of $100 \mathrm{~mA}$. The test frequency range was from $1 \mathrm{MHz}$ to $0.01 \mathrm{~Hz}$ unless special denotation and 20 points were measured at each decade. The fitting of the impedance data was performed with software ZVIEW. ${ }^{19}$

Current interruption method was applied to evaluate the ohmic resistance under current load. It was fulfilled via a current pulse generator (HC2005, Hokuto Denko corp.). The current load was $0.22 \mathrm{~A} \mathrm{~cm}^{-2}$. The discharge operation was interrupted once each $10 \mathrm{~min}$ and the time of holding at $\mathrm{OCV}$ was $300 \mathrm{~ms}$. The ohmic resistance $R_{o}$ estimated by current interruption method is calculated by

$$
R_{o}=\frac{V_{a}-V_{b}}{I}
$$

where $V_{a}$ is the voltage soon after the current interruption, $V_{b}$ is the voltage before the current interruption and $I$ is the current density loaded.

\section{Results}

The first current load for as-prepared cell.- To reduce the gas diffusion resistance in the anode, a gaseous mixture of $36.4 \% \mathrm{H}_{2}-$ $33.6 \% \mathrm{H}_{2} \mathrm{O}-30 \% \mathrm{~N}_{2}$ was supplied with a sufficient flow rate of $432 \mathrm{~mL} \mathrm{~min}^{-1}$. The cathode gas composed of $21 \% \mathrm{O}_{2}-79 \% \mathrm{~N}_{2}$ was

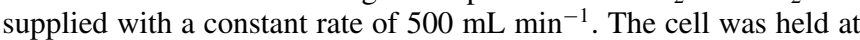
OCV for $130 \mathrm{~h}$ before discharge, but no discernible changes were observed in the impedance spectra during this holding process. Figure 2 shows the time course of output voltage with a current density of $0.15 \mathrm{~A} \mathrm{~cm}^{-2}$ at $900^{\circ} \mathrm{C}$. Discharge operation was conducted for $216 \mathrm{~h}$, and the current was cut off periodically to test the impedance at $\mathrm{OCV}$.
For each time period, a significant decrease in the initial cell performance was found. Furthermore, the obtained output voltage was reduced gradually with time up to $144 \mathrm{~h}$, and then almost steady state was achieved. These results are different from the general observations, in which the initial cell performance shows a significant improvement with a supply of constant current. ${ }^{1,2}$

Figure 3a shows the impedance spectra measured periodically at OCV during the interval of the current loads of $0.15 \mathrm{~A} \mathrm{~cm}^{-2}$ at $900^{\circ} \mathrm{C}$ in Fig. 2. Due to the strong disturbance of high-frequency inductance caused by long lead wires and insufficient electromagnetic shielding, the high-frequency intercepts of the impedance spectra with the real axis appeared at $1778 \sim 1995 \mathrm{~Hz}$. The impedance arc at $\sim 200 \mathrm{~Hz}$ shrank with time, whereas the high-frequency intercept with the real axis increased significantly. The changes in the low-frequency region

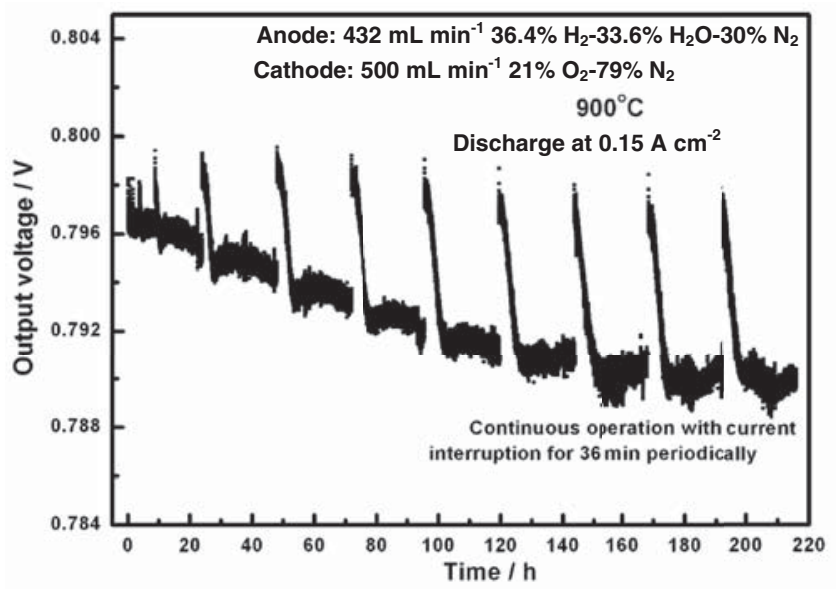

Figure 2. The time course of the cell output voltage with a current load of $0.15 \mathrm{~A} \mathrm{~cm}^{-2}$ at $900^{\circ} \mathrm{C}$ for the as-prepared cell. 

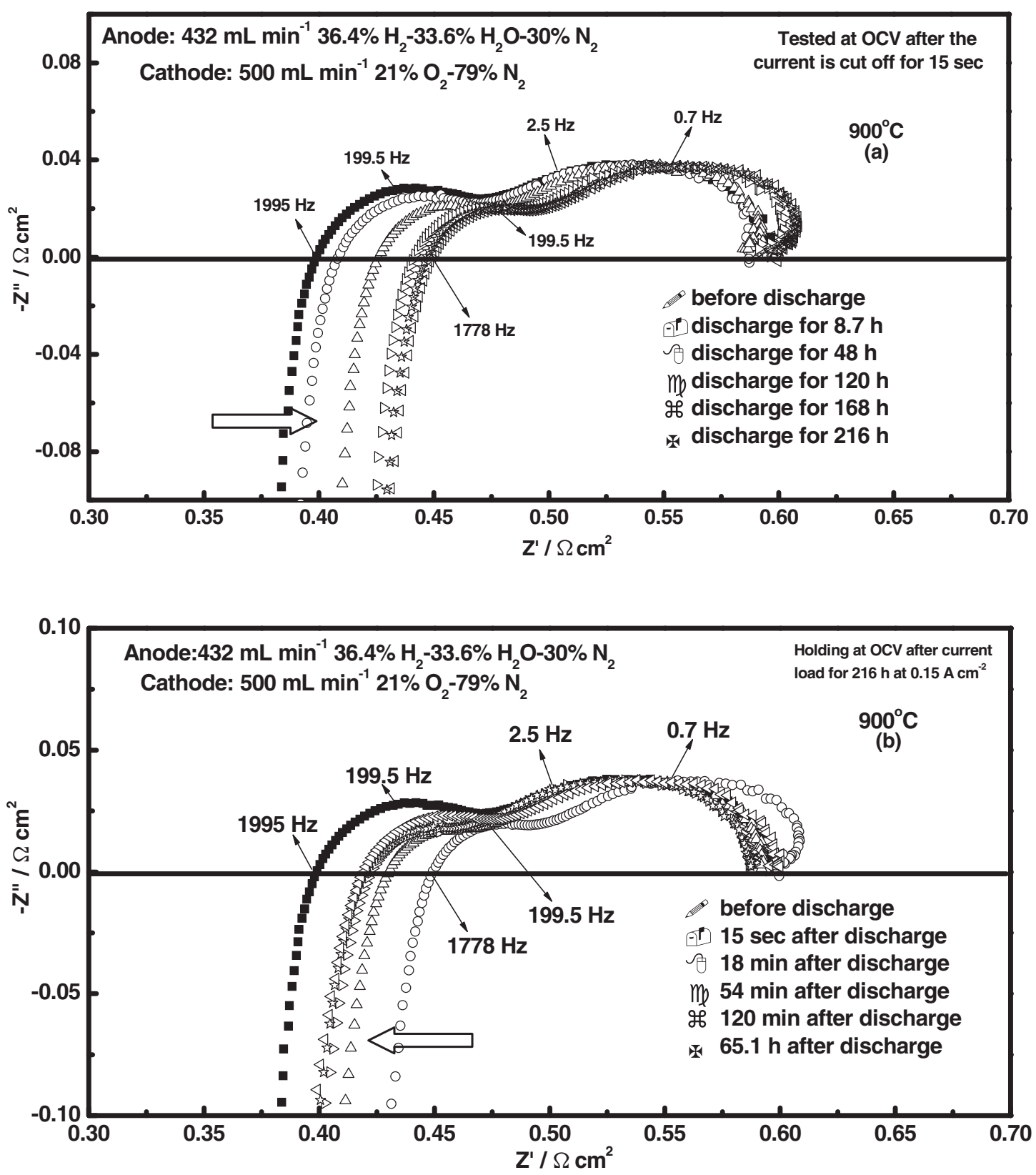

Figure 3. Impedance spectra tested at $\mathrm{OCV}$ during the current load of $0.15 \mathrm{~A} \mathrm{~cm}^{-2}$ for $216 \mathrm{~h}$ (a) and tested during subsequently holding at $\mathrm{OCV}$ (b).

of the spectra below $3 \mathrm{~Hz}$ were small. With the prolonged time, the measured impedance spectra gradually approached a steady state. The impedance spectra over time during subsequent holding at OCV after operating at $0.15 \mathrm{~A} \mathrm{~cm}^{-2}$ for $216 \mathrm{~h}$ are displayed in Figure $3 \mathrm{~b}$. Both the high-frequency intercept with the real axis and the arc at $\sim 200 \mathrm{~Hz}$ rapidly recovered toward the starting values before the current load. Although their recoveries were incomplete, the response in Fig. 2 and impedance change in Fig. 3 are expected to be reversible process induced by the sudden and forced current interruptions. Because the other components of impedance showed only modest increases upon discharge, the initial change in cell performance should be associated with the increase of the high-frequency intercept with the real axis.

For this segmented-in-series cell, we have demonstrated previously that the impedance arc corresponding to cathode oxygen ion transport through LSM/YSZ interface and YSZ of the composite cathode appears at or over $10 \mathrm{kHz}$ and the electrochemical reaction at the anodic TPB appears at $\sim 1000 \mathrm{~Hz}{ }^{15}$ The impedance arc at $\sim 200 \mathrm{~Hz}$ is assigned to the oxygen reduction process in the cathode. The impedance arc below $3 \mathrm{~Hz}$ is attributed to the gas diffusion resistance in both electrodes. ${ }^{16}$ Thus, the shrinkage of the semicircle at $\sim 200 \mathrm{~Hz}$ upon discharge can be considered as the cathode activation induced by the generation of oxygen vacancies. Once the current is cut off, newly-generated oxygen vacancies are re-occupied by the dissociated adsorption of molecular oxygen, which can lead to the recovery of this impedance arc. The high-frequency intercept with the real axis at $\sim 1778 \mathrm{~Hz}$ includes the contributions of charge transfer reaction at the anodic TPB, oxygen ion transfer through LSM/YSZ interface and YSZ particles, and ohmic resistance. In the next section, then, the dominant electrode process for the increase-recovery of the highfrequency intercept on the real axis was investigated by the current load cycling test under various atmospheres. 


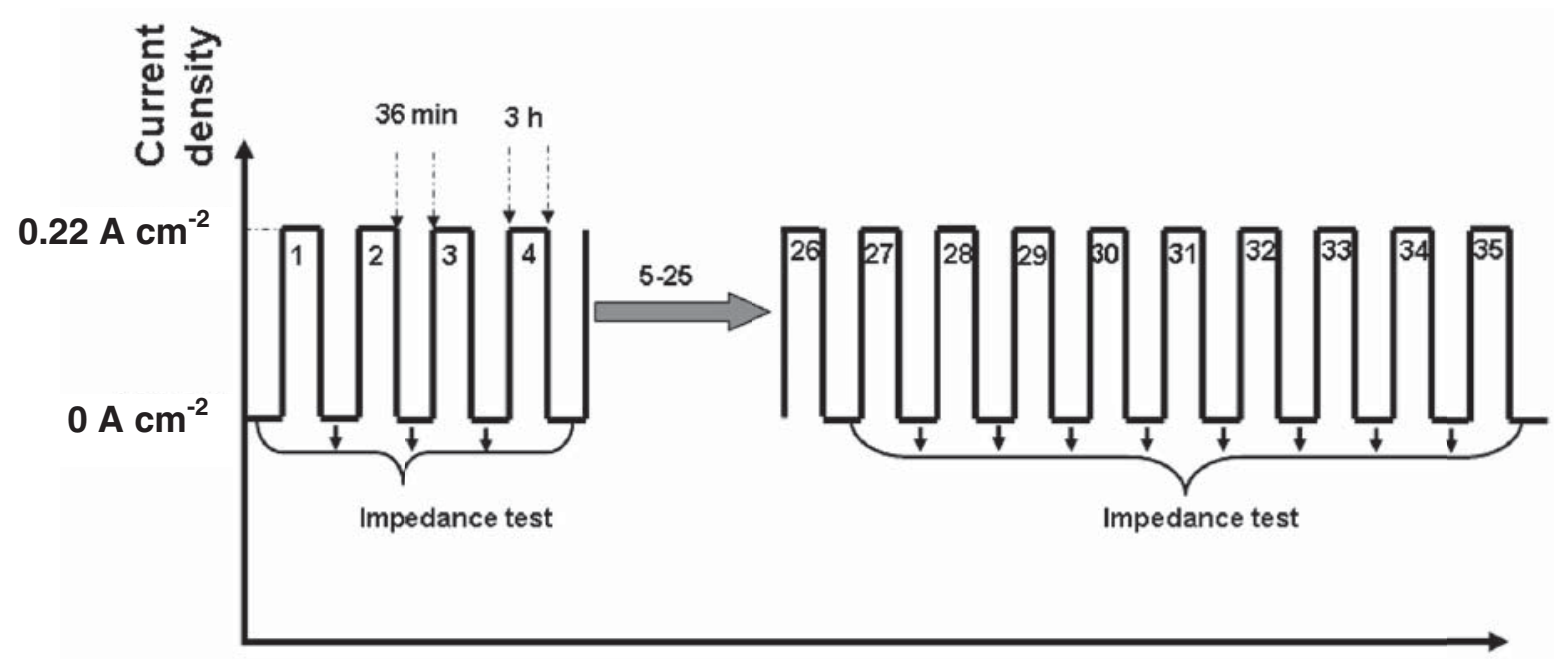

Time

Figure 4. A schematic diagram of current load cycling.

Current load cycling.- Figure 4 shows the schematic operation schedule of current load cycling test. The cell was continuously switched between the current load of $0.22 \mathrm{~A} \mathrm{~cm}^{-2}$ for $3 \mathrm{~h}$ and $0 \mathrm{~A} \mathrm{~cm}^{-2}$ for $36 \mathrm{~min}$. The impedance test was started just after switching the cell to $0 \mathrm{~A} \mathrm{~cm}^{-2}$ for $15 \mathrm{sec}$ for each cycle. Figure 5 shows the variations of output voltage at $0.22 \mathrm{~A} \mathrm{~cm}^{-2}$ with an elapse of time during initial 35 cycles under different partial pressure of steam, $P\left(\mathrm{H}_{2} \mathrm{O}\right)$, in the anode. In these measurements, oxygen was supplied to the cathode at $500 \mathrm{~mL} \mathrm{~min}{ }^{-1}$. The cell performance was stable throughout $100 \mathrm{~h}$ of operation with the cyclic current change in every $P\left(\mathrm{H}_{2} \mathrm{O}\right)$ in the anode gas up to $0.336 \mathrm{~atm}$. In response to this behavior, no changes in impedance spectra were found during each current load cycle, as was not shown here. Therefore, the initial spiky response and gradual decrease in cell performance observed in Fig. 2 was not attributed to the anode.

Then, the detailed investigation focused on the cathodic reaction and condition. The variations of the output voltage at $0.22 \mathrm{~A} \mathrm{~cm}^{-2}$ under different partial pressure of oxygen, $P\left(\mathrm{O}_{2}\right)$, in the cathode are shown in Fig. 6. In these measurements, the anode gas composition was fixed at $36.4 \% \mathrm{H}_{2}-33.6 \% \mathrm{H}_{2} \mathrm{O}-30 \% \mathrm{~N}_{2}$ with a flow rate of

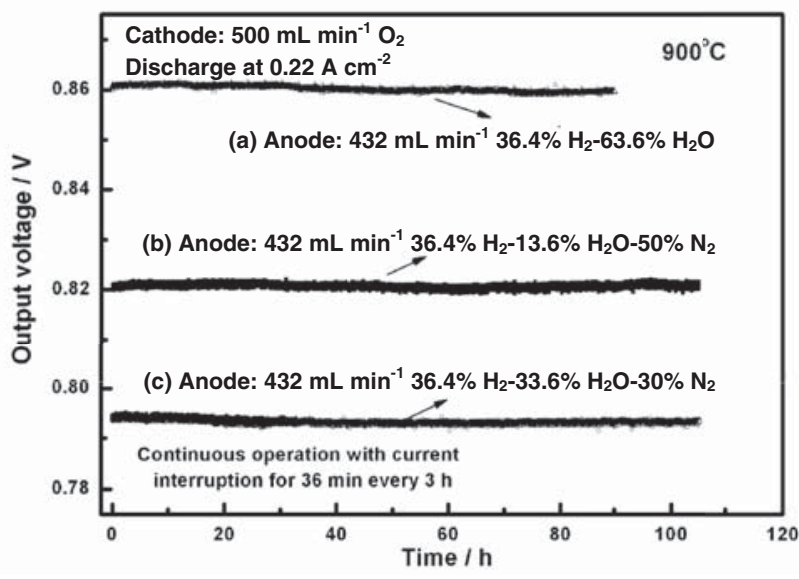

Figure 5. The variation of output voltage with time under cycling the current load of $0.22 \mathrm{~A} \mathrm{~cm}^{-2}$ at different $P\left(\mathrm{H}_{2} \mathrm{O}\right)$ in the anode.
$432 \mathrm{~mL} \mathrm{~min}^{-1}$. Except for the cathode gas condition at $P\left(\mathrm{O}_{2}\right)=1 \mathrm{~atm}$, the cell performance was deteriorated during the initial stage of current load and the lower $P\left(\mathrm{O}_{2}\right)$ resulted in a more severe deterioration. Figure 7 shows the impedance spectra tested at OCV during the above current load cycling and subsequent holding under different $P\left(\mathrm{O}_{2}\right)$ in the cathode chamber. The impedance spectra kept unchanged throughout this measurement at $P\left(\mathrm{O}_{2}\right)=1 \mathrm{~atm}$. Under the lower $P\left(\mathrm{O}_{2}\right)$ conditions the impedance arc at $\sim 200 \mathrm{~Hz}$ shrunk, while the highfrequency intercept with the real axis increased with the progress of the cycles. After the current was cut off, the impedance spectra, especially the high-frequency intercepts, rapidly recovered toward the initial state before the current load. The above-mentioned behavior became more obvious as the $P\left(\mathrm{O}_{2}\right)$ in the cathode was lowered. Considering the rapid recovery of the high-frequency intercept with the real axis after the current cutoff, it is expected that the impedance spectra tested from low-frequency to high-frequency at OCV should not change significantly with the discharge time. This is because it takes long time to measure the low-frequency impedance component.

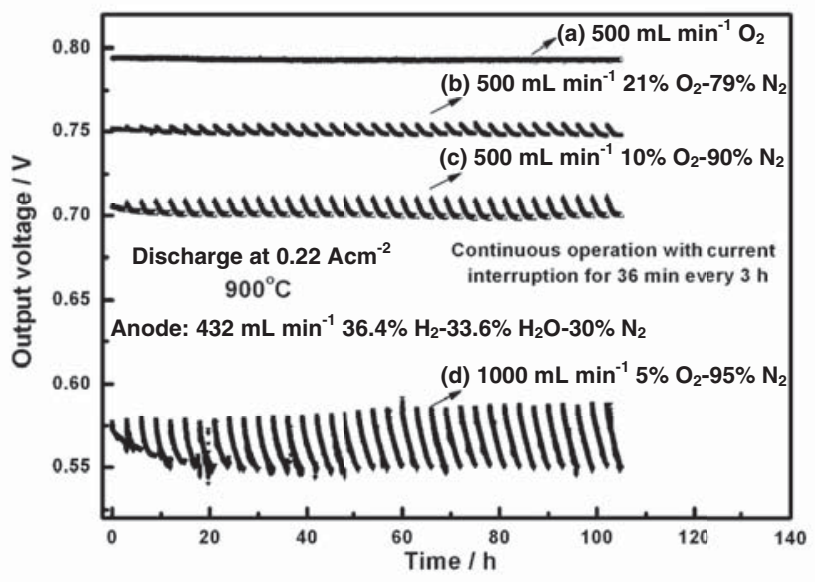

Figure 6. The variation of output voltage with time under cycling the current load of $0.22 \mathrm{~A} \mathrm{~cm}^{-2}$ at different $P\left(\mathrm{O}_{2}\right)$ in the cathode. 

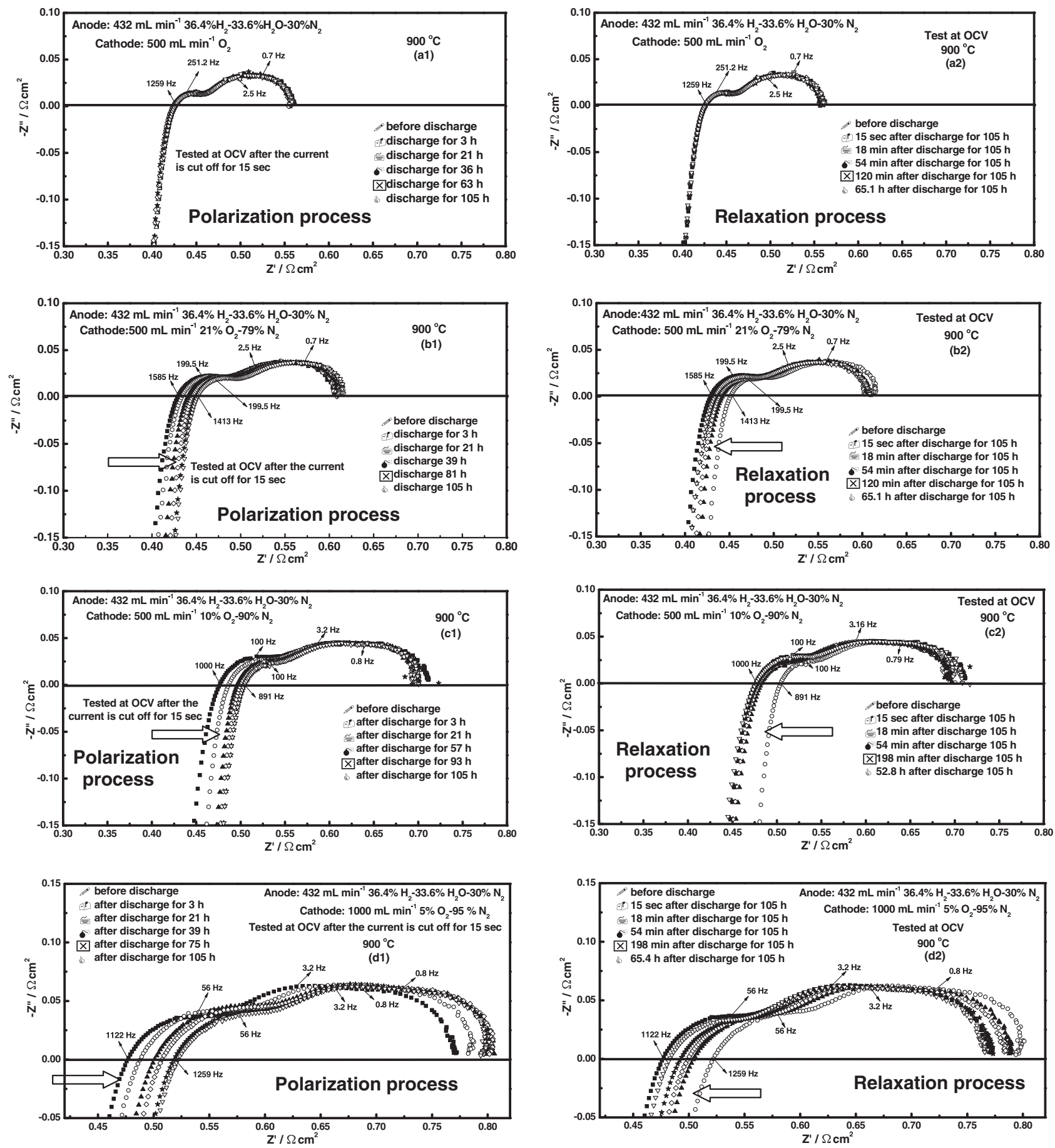

Figure 7. Impedance spectra tested under cycling the current load of $0.22 \mathrm{~A} \mathrm{~cm}^{-2}(\mathrm{a} 1, \mathrm{~b} 1, \mathrm{c} 1, \mathrm{~d} 1)$ and subsequently holding at OCV (a2, b2, c2, d2) at different $P\left(\mathrm{O}_{2}\right)$ in the cathode.

Figure 8 shows the impedance spectra tested from $0.01 \mathrm{~Hz}$ to $1 \mathrm{MHz}$ over time during the current load cycling at $P\left(\mathrm{O}_{2}\right)=0.1 \mathrm{~atm}$. Note that the impedance spectra did not show apparent changes. This result further indicates that the relaxation of the high-frequency intercept with the real axis is a very fast process. Then, the current interruption measurements were conducted to monitor the change in ohmic resistance during the 15th discharge in $10 \% \mathrm{O}_{2}-90 \% \mathrm{~N}_{2}$, as shown in Fig. 9. Within the first $1 \mathrm{~h}$ a rapid increase in the ohmic resistance was confirmed, and then the almost steady value was obtained. This behavior agreed well with the change in cell performance as observed in Fig. 2. Thus, the increase-recovery behavior of the high-frequency intercept with the real axis in impedance spectra should be related to the change in ohmic resistance.

\section{Discussion}

The initial decrease in cell performance and the concomitant increase in ohmic resistance were strongly affected by $P\left(\mathrm{O}_{2}\right)$ at the cathode side under current load. The overpotential of the cathodic reaction is extracted from Eq. 2. Then the partial pressure of oxygen at the cathode/electrolyte interface, $P\left(\mathrm{O}_{2}\right.$-interface $)$, under current load with $0.22 \mathrm{~A} \mathrm{~cm}^{-2}$ was hypothetically estimated by using Eq. 3 


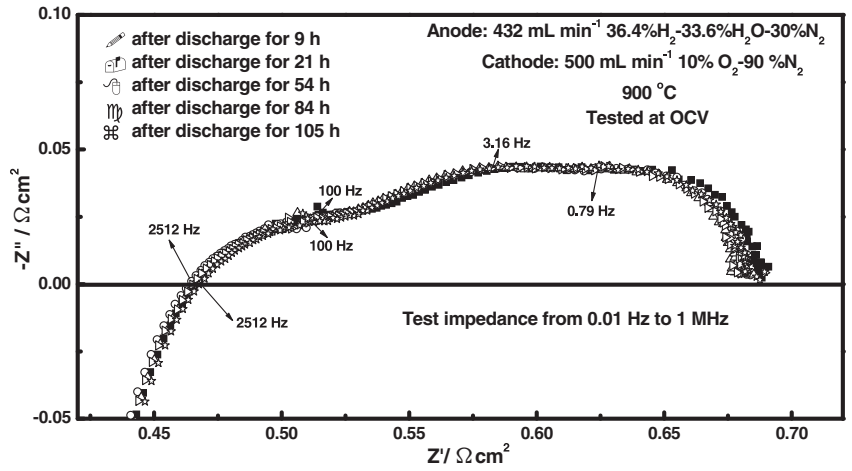

Figure 8. Impedance spectra tested from low-frequency to high-frequency under cycling the current load of $0.22 \mathrm{~A} \mathrm{~cm}^{-2}$ at $900{ }^{\circ} \mathrm{C}$ in $10 \% \mathrm{O}_{2}-90 \% \mathrm{~N}_{2}$.

(see Table I).

$$
\begin{gathered}
\eta_{\text {cathode }}=E^{o}-V-\left(R_{o}+R_{a}\right) J \\
\eta_{\text {cathode }}=\frac{R T}{4 F} \ln \left(\frac{P\left(\mathrm{O}_{2}-\text { surface }\right)}{P\left(\mathrm{O}_{2}-\text { interface }\right)}\right)
\end{gathered}
$$

where $\eta_{\text {cathode }}$ is the cathodic overpotential, $P\left(\mathrm{O}_{2}\right.$-surface $)$ is the partial pressure of oxygen at the cathode surface, $E^{o}$ is OCV, $V$ is the output voltage under current density $J, R_{o}$ and $R_{a}$ are ohmic resistance and anodic polarization resistance, respectively. Both $R_{o}$ and $R_{a}$ are estimated from fitting the impedance spectra under current load with an equivalent circuit shown in Refs. 15 and 16. For $R_{a}$, only the anodic gas diffusion resistance was considered because of the fast electrochemical hydrogen oxidation process at this temperature. From Table I, it is apparent that even in the case of $5 \% \quad \mathrm{O}_{2}-95 \% \mathrm{~N}_{2}$ the $P\left(\mathrm{O}_{2}-\right.$ interface) is only $1.7 \times 10^{-5}$ atm. The electrical conductivity of YSZ is constant down to $P\left(\mathrm{O}_{2}\right)=10^{-25}$ atm, ${ }^{20,21}$ and that of LSM is also stable down to $P\left(\mathrm{O}_{2}\right)=10^{-10}$ atm at $1000^{\circ} \mathrm{C}^{22-24}$ In these experimental conditions, therefore, the intrinsic electrical conductivities of LSM and YSZ should be unaffected by $P\left(\mathrm{O}_{2}\right.$-interface $)$ under current load.

Among the various factors, the element interdiffusion between LSM cathode and YSZ electrolyte is strongly related to this behavior. For the cell used in this study, LSM cathode was sintered on YSZ electrolyte over $1300^{\circ} \mathrm{C}$ for $2 \mathrm{~h}$ in the fabrication process. Such high

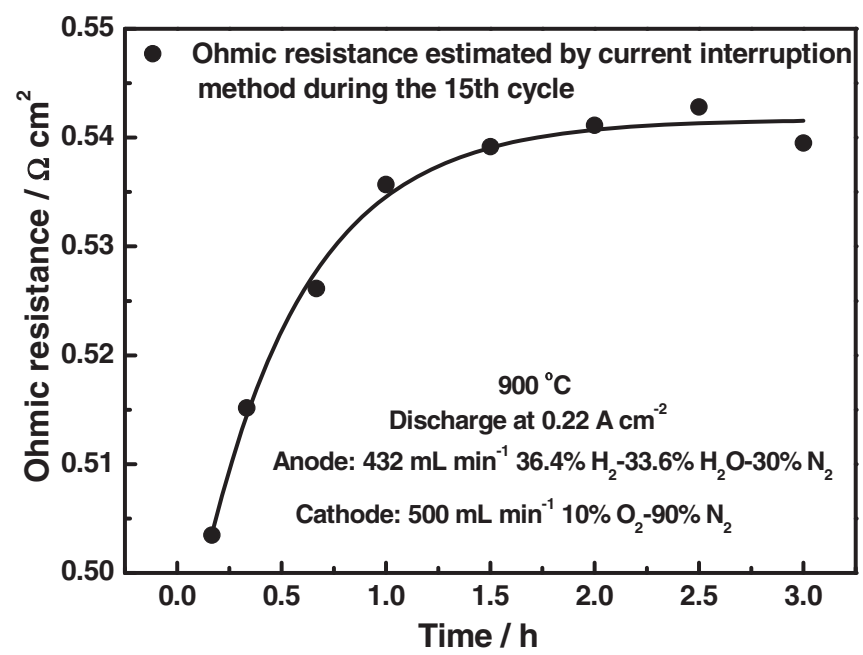

Figure 9. Ohmic resistance tested via current interruption method under the current load of $0.22 \mathrm{~A} \mathrm{~cm}^{-2}$ at $900^{\circ} \mathrm{C}$ for the 15 th discharge in $10 \%$ $\mathrm{O}_{2}-90 \% \mathrm{~N}_{2}$.

$\begin{aligned} & \text { Table I. Estimated } \boldsymbol{P}\left(\mathrm{O}_{2} \text {-interface }\right) \text { at cathode/electrolyte interface } \\
& \text { under the current load of } \mathbf{0 . 2 2} \mathbf{A ~ c m}^{-2} \text { at different } \boldsymbol{P}\left(\mathbf{O}_{2}\right) \text {. }\end{aligned}$
\begin{tabular}{lcc} 
Gas & Cathode overpotential $(\mathrm{mV})$ & $P\left(\mathrm{O}_{2}\right.$-interface) (atm) \\
\hline $\mathrm{O}_{2}$ & 19 & $4.7 \times 10^{-1}$ \\
$21 \% \mathrm{O}_{2}-79 \% \mathrm{~N}_{2}$ & 37 & $4.8 \times 10^{-2}$ \\
$10 \% \mathrm{O}_{2}-90 \% \mathrm{~N}_{2}$ & 65 & $7.8 \times 10^{-3}$ \\
$5 \% \mathrm{O}_{2}-95 \% \mathrm{~N}_{2}$ & 202 & $1.7 \times 10^{-5}$
\end{tabular}

temperature processing results in the Mn dissolution into YSZ by grain boundary diffusion as well as the formation of insulating layers such as $\mathrm{La}_{2} \mathrm{Zr}_{2} \mathrm{O}_{7}$ and $\mathrm{SrZrO}_{3} .{ }^{25-28}$ It is well known that these solid state reactions lead to a significant decrease in the cell electrical conductivity. For example, $5 \mathrm{~mol} \% \mathrm{Mn}$-doped YSZ only has a half of the electrical conductivity of pure $\mathrm{YSZ}$ at $850^{\circ} \mathrm{C},{ }^{29}$ and the electrical conductivities of both zirconates are about three orders of magnitude lower than that of YSZ. ${ }^{30-32}$ However, the influence of zirconate phases will be minimized because these phases disappear during the first current load, as was confirmed by other researchers. ${ }^{7,8}$ Therefore we have to focus on the electrochemical properties of Mn-doped YSZ. Several studies ${ }^{28,29,33}$ has shown that the electrical conductivity of Mndoped YSZ remarkably reduces with decreasing $P\left(\mathrm{O}_{2}\right)$. For $4 \mathrm{~mol} \%$ Mn-doped YSZ, the conductivity is $1.5 \times 10^{-1} \mathrm{~S} \mathrm{~cm}^{-1}$ in air, whereas it turns to be $4.8 \times 10^{-2} \mathrm{~S} \mathrm{~cm}^{-1}$ in $10^{-5} \mathrm{~Pa}$ at $1000^{\circ} \mathrm{C}^{28}$ Most manganese dissolved into YSZ exists as $\mathrm{Mn}^{3+}$ in air. ${ }^{34}$ With decreasing $P\left(\mathrm{O}_{2}\right)$, the oxidation state of manganese species gradually changes from $3+$ to $2+$, which causes the generation of excessive amount of oxygen vacancies. Thus the association of oxygen vacancies and cations leads to the reduction in the electrical conductivity. ${ }^{29}$ Another explanation regarding the reduction in electrical conductivity is the chemical property change in the grain boundary glass phase due to the increased ionic radius of $\mathrm{Mn}^{2+} .33$ The decrease-recovery behavior of the electrical conductivity of Mn-doped YSZ upon the atmosphere exchange experiments (oxidizing $\rightarrow$ reducing $\rightarrow$ oxidizing) has also been observed. ${ }^{33}$ So the similar behavior is expected to take place in this study. Since $P\left(\mathrm{O}_{2}\right.$-interface $)$ decreases under current load, $\mathrm{Mn}^{3+}$ dissolved into YSZ is reduced to $\mathrm{Mn}^{2+}$ and then the electrical conductivity decreases. Once the current is cut off, $P\left(\mathrm{O}_{2}\right.$-interface $)$ recovers toward that at $\mathrm{OCV}$, leading to the oxidation of $\mathrm{Mn}^{2+}$ to $\mathrm{Mn}^{3+}$ and the concomitant decrease in ohmic resistance. Besides the dissolution of manganese into YSZ electrolyte occurring during cell fabrication, the formation of oxygen potential gradient under discharge can also accelerate manganese migration into YSZ electrolyte surface, which has been identified by Jorgensen et al. ${ }^{35}$ and Backhaus-Ricoult et al. ${ }^{6}$ This can lead to the further increase of the cell ohmic resistance during long-term operation. Since a series of these factors affect the dynamic behavior of cells, the cell fabrication process and the discharge conditions have to control carefully for the stable prolonged operation.

\section{Conclusions}

In this study, dynamic behavior of the Mitsubishi segmented-inseries tubular SOFC has been investigated. A significant decrease of the cell performance during the initial period upon discharge was observed at $900^{\circ} \mathrm{C}$. Lower $P\left(\mathrm{O}_{2}\right)$ in the cathode resulted in a more severe decrease in initial cell performance, whereas the anode gas composition did not affect such decreasing behavior. The initial decrease in cell performance was accompanied by the increase of ohmic resistance. As the current was cut off, the ohmic resistance rapidly recovered to the starting value before discharge in a short-term operation. The increase of the ohmic resistance is likely to be related to the reduction of $\mathrm{Mn}^{3+}$ dissolved in YSZ electrolyte during cell fabrication. 


\section{Acknowledgment}

This work was supported by New Energy and Industrial Technology Development Organization (NEDO), Japan (Development of System and Elemental Technology on Solid Oxide Fuel Cell).

\section{References}

1. V. A. C. Haanappel, A. Mai, and J. Mertens, Solid State Ionics, 177, 2033 (2006)

2. S. Koch, M. Mogensen, P. V. Hendriksen, N. Dekker, and B. Rietveld, Fuel cells, 6, 117 (2006)

3. R. J. Aaberg, R. Tunold, M. Mogensen, R. W. Berg, and R. Odegard, J. Electrochem. Soc., 145, 2244 (1998).

4. H. Y. Lee, W. S. Cho, S. M. Oh, H.-D. Wiemhofer, and W. Gopel, J. Electrochem. Soc., 142, 2659 (1995).

5. M. Backhaus-Ricoult, Solid State Ionics, 177, 2195 (2006).

6. M. Backhaus-Ricoult, K. Adib, T. S. Clair, B. Luerssen, L. Gregoratti, and A. Barinov, Solid State Ionics, 179, 891 (2008).

7. H. Yokokawa, Annu. Rev. Mater. Res., 33, 581 (2003).

8. A. Weber, R. Manner, R. Waser, and E. Ivers-Tiffee, Electrochemistry, 64, 582 (1996).

9. S. P. Jiang and J. G. Love, Solid State Ionics, 138, 183 (2001).

10. A. A. Vance and S. Mcintosh, J. Electrochem. Soc., 155, B1 (2008).

11. M. A. Haider and S. Mcintosh, J. Electrochem. Soc., 156, B1369 (2009).

12. T. Matsui, Y. Mikami, H. Muroyama, and K. Eguchi, J. Electrochem. Soc., 157, B1790 (2010).

13. M. Kuznecov, P. Otschik, P. Obenaus, K. Eichler, and W. Schaffrath, Solid State Ionics, 138, 183 (2001).

14. S. P. Jiang, J. Solid State Electrochem., 11, 93 (2007).

15. B. Liu, H. Muroyama, T. Matsui, K. Tomida, T. Kabata, and K. Eguchi, J. Electrochem. Soc., 157, B1858 (2010)
16. B. Liu, H. Muroyama, T. Matsui, K. Tomida, T. Kabata, and K. Eguchi, J. Electrochem. Soc., 158, B215 (2011).

17. K. Tomida, N. Hisatome, T. Kabata, H. Tsukuda, and Y. Yamazaki, Electrochemistry, 77, 379 (2009).

18. K. Tomida, N. Hisatome, T. Kabata, H. Tsukuda, and Y. Yamazaki, Electrochemistry, 77, 865 (2009).

19. D. Johnson, ZPLOT, ZVIEW ELECTROCHEMICAL IMPEDANCE SOFTWARE version 3.1. Scribner Associate, Inc. (2007).

20. T. H. Etsell and S. N. Flengas, Chem. Rev., 70, 339 (1970)

21. J.-H. park and R. N. Blumenthal, J. Electrochem. Soc., 136, 2867 (1989).

22. J. H. Kuo, H. U. Anderson, and D. M. Sparlin, J. Solid State Chem., 87, 55 (1990).

23. H. kamata, Y. Yonemura, J. Mizusaki, H. Tagawa, K. Naraya, and T. Sasamoto, J. Phys.Chem. Solids, 56, 943 (1995)

24. J. Nowothy and M. Rekas, J. Am. Ceram. Soc., 81, 67 (1998).

25. K. Wiik, C. R. Schmidt, S. Faaland, S. Shamsili, M.-A. Einarsrud, and T. Grande, J. Am. Ceram. Soc., 82, 721 (1999).

26. A. Chen, G. Bourne, K. Siebein, R. Dehoff, E. Wachsman, and K. Jones, J. Am. Ceram. Soc., 91, 2670 (2008).

27. C. Levy, Y. Zhong, C. Morel, and S. Marlin, J. Electrochem. Soc., 157, B1597 (2010).

28. T. Kawada, N. Sakai, H. Yokokawa, and M. Dokiya, Solid State Ionics, 53-56, 418 (1992).

29. T. Kawada, N. Sakai, H. Yokokawa, and M. Dokiya, Solid State Ionics, 50, 189 (1992).

30. H. Y. Lee and S. M. Oh, Solid State Ionics, 90, 133 (1996)

31. F. W. Poulsen and N. V. D. Puil, Solid State Ionics, 53-56, 777 (1992).

32. J. A. Labrincha, J. R. Frade, and M. B. Marques, J. Mater. Sci., 28, 3809 (1993).

33. D. Lybye, Y-L Liu, M. Mogensen, and S. Linderoth, Proc. 9th International Symposium on Solid Oxide Fuel Cells (SOFC-IX), (Eds. S. C. Singhal and J. Mizusaki), Quebec, Canada, 2005, 954

34. K. Sasaki and J. Maier, Phys. Chem. Chem. Phys., 2, 3055 (2000).

35. M. J. Jorgensen, P. Holtappels, and C. C. Appel, J. Applied Electrochem., 30, 411 (2000). 